\title{
Obituary: Toshiyuki Fukao (1961-2020), a friend of the Latin American IEM community
}

\author{
Hiroyuki Ida ${ }^{1, *}$
}

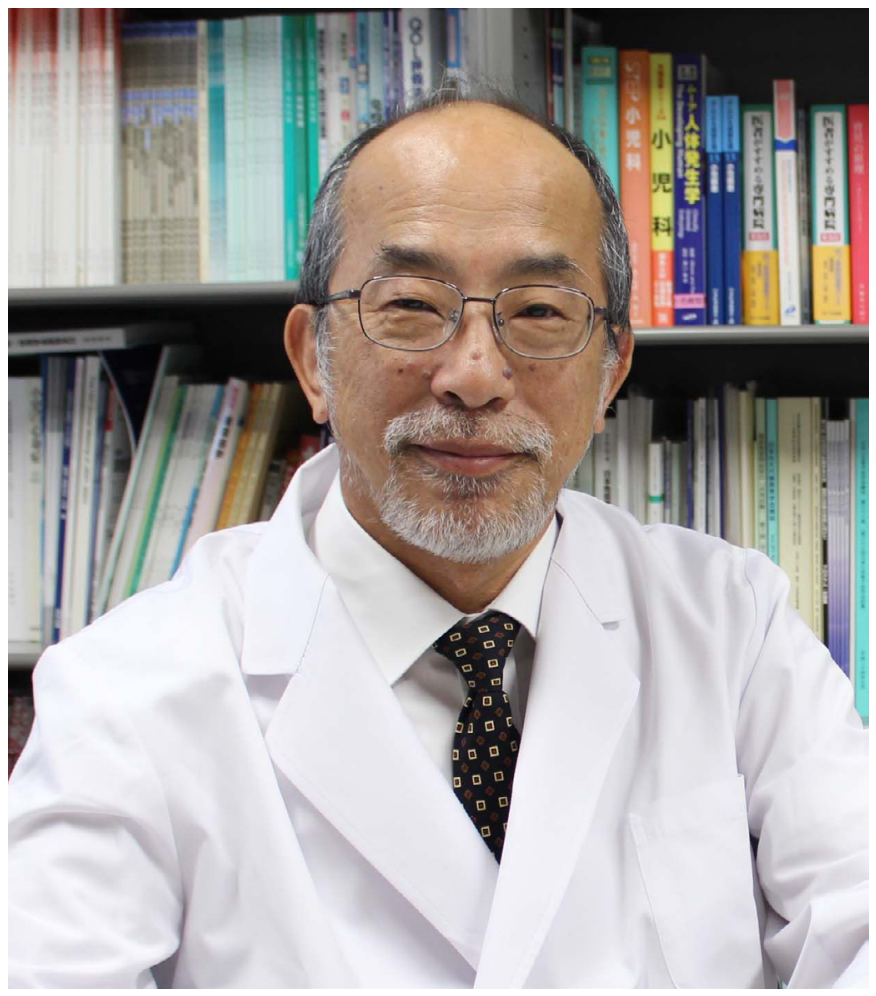

\section{Dr. Toshiyuki Fukao}

Professor, Department of Pediatrics,

Graduate School of Medicine, Gifu University, Gifu, Japan (1961-2020)

It is very sad to inform you that Professor Toshiyuki Fukao (Toshi) passed away at the age of 58. Since he was too young and he deceased suddenly, I cannot believe that he is not here.

Professor Fukao graduated from the Mie University School of Medicine in 1985. He was admitted to the Medical School in Gifu University School of Medicine in 1987. Then he studied Biochemistry under the mentoring of Professor Takashi Hashimoto in Shinshu University School of Medicine from
Journal of Inborn Errors

of Metabolism \& Screening

2020, Volume 8: e20200101

DOI: 10.1590/2326-4594-JIEMS-2020-08-01

1988 to 1990 . He was trained in Pediatrics in Gifu University under the mentoring of Professor Tadao Orii from 1990 to 2000. In the following years, he was trained in the Queensland Institute of Medical Research in Australia from 2000 to 2001. Back to Japan, he was appointed as an Assistant Professor in 2002, Associate Professor in 2004, and Full Professor in 2013 at the Department of Pediatrics, Graduate School of Medicine, Gifu University, Gifu in Japan.

Professor Fukao has worked as a representative of the Japanese Society for Inherited Metabolic Diseases (JSIMD) since 2003, Japanese Society of Human Genetics (JSHG) since 2004, and Japanese Pediatric Society since 2008. He is one of the key opinion leaders of ketone body metabolism research. He has published many papers regarding defects in ketone synthesis pathway and ketone utilization. As a result of academic achievements, he received the Young Investigator Award from JSIMD in 1993 and JSHG in 1998. Since he has made great efforts to develop JSIMD, he was appointed as a Board member in 2010 and received the JSIMD Society Award in 2012. He organized the 2018 Annual Meeting of JSIMD. Many participants and speakers from not only Japan but from all the continents enjoyed the talks as well as the beauty of the Japanese fall. As described here, Professor Fukao has made great contributions to development of JSIMD. Based on his achievement and his popularity from members of JSIMD, he was appointed the $6^{\text {th }}$ chairman of the Board of Directors of JSIMD in 2019.

${ }^{1}$ Jikei University, School of Medicine, Department of Pediatrics, Tokyo, Japan *Hiroyuki Ida, M.D. The $5^{\text {th }}$ Chairman of JSIMD. Executive Chairman and Professor, Department of Pediatrics, The Jikei University School of Medicine, Tokyo, Japan

\section{Corresponding Author:}

Hiroyuki Ida, Jikei University, School of Medicine, Department of Pediatrics, Tokyo, Japan

Email: hiroy@jikei.ac.jp 
Professor Fukao cloned cDNAs and genes encoding human mitochondrial Acetoacetyl-CoA Thiolase (T2) and Succinyl CoA:3-ketoacid CoA Transferase (SCOT). These results were published in top journals of the metabolic field $[1,2,3,4]$. He identified and reported the first Japanese patient with SCOT deficiency [5]. He analyzed mutated enzyme protein of T2 and SCOT and then shed light on the relationship between residual activity and clinical expression of patients with $\mathrm{T} 2$ and SCOT deficiency, and published these data $[6,7,8,9]$. Moreover, he published overviews of ketone body metabolism in several book chapters and manuscripts $[7,10,11,12,13,14]$.
I have worked with Professor Fukao for a long time as Executive Member of JSIMD. We always talked about and consider how to develop JSIMD and the next generation of JSIMD members. We have made efforts to increase JSIMD's international recognition. In September 2019, we attended the SSIEM in Rotterdam in order to attract the International Congress of IEM (ICIEM) to Japan. We had an informal agreement that the JSIMD will organize ICIEM in 2025 and if Prof Fukao were alive, he would be the president of the congress. I regret that I lost a sworn friend and that Toshi cannot accomplish all the things that he wanted to do.

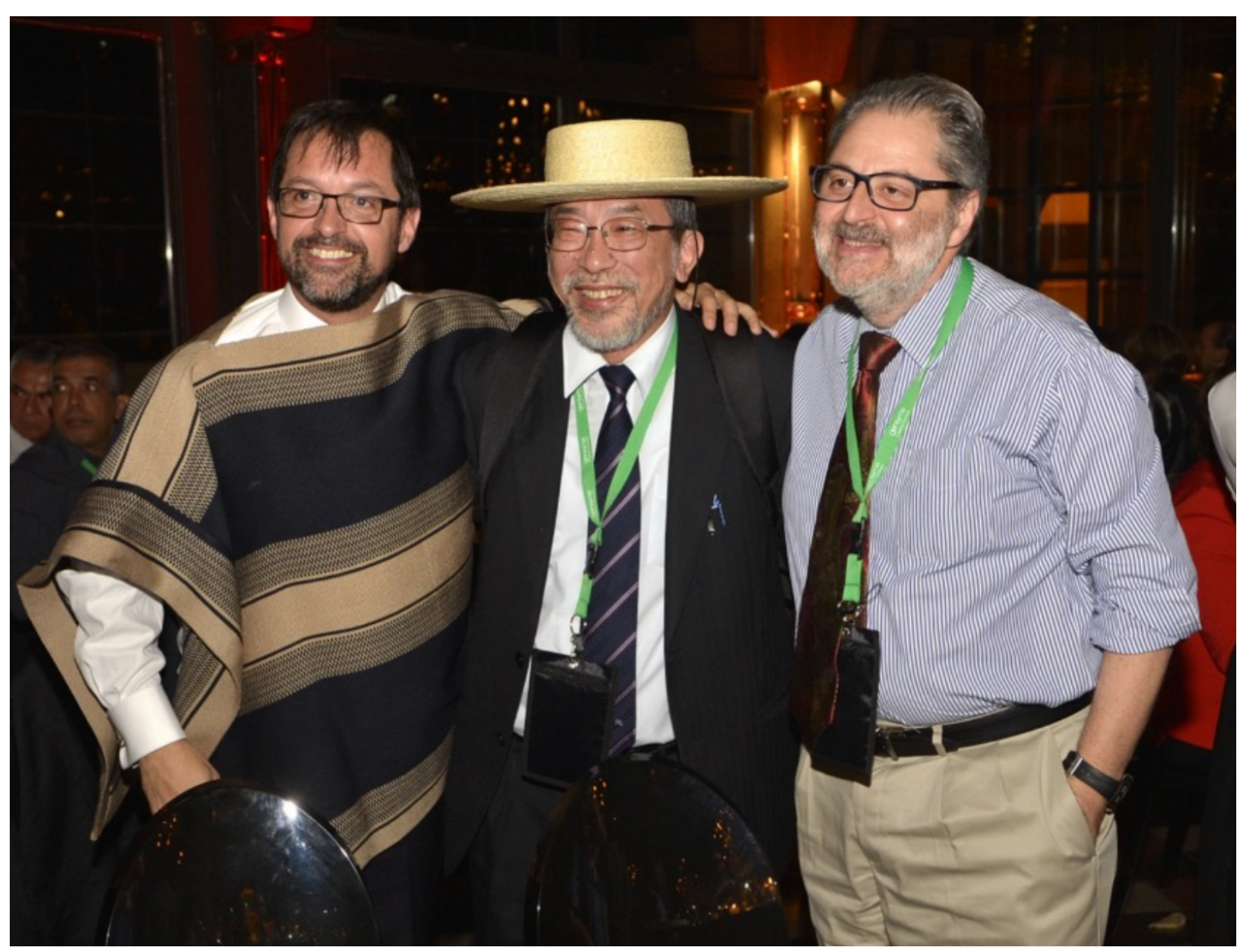

Dr Fukao (center) at the X SLEIMPN Congress (Santiago, Chile, 2015), between the SLEIMPN Chairs, Dr Juan Francisco Cabello (left), and Dr. José Abdenur (right). 


\section{References}

1. Fukao T, Yamaguchi S, Kano M, Orii T, Fujiki Y, Osumi T, Hashimoto T. Molecular cloning and sequence of the complementary DNA encoding human mitochondrial acetoacetyl-coenzyme A thiolase and study of the variant enzymes in cultured fibroblasts from patients with 3-ketothiolase deficiency. J Clin Invest. 1990;86(6):20622070. doi:10.1172/jci114943

2. Masatsugu K, Fukao T, Yamaguchi S, Orii T, Osumi T, Hashimoto T. Structure and expression of the human mitochondrial acetoacetyl-CoA thiolase-encoding gene. Gene. 1991;109(2):285-290. doi:10.1016/03781119(91)90623-J

3. Kassovska-Bratinova S, Fukao T, Song XQ, et al. Succinyl CoA: 3-oxoacid CoA transferase (SCOT): human cDNA cloning, human chromosomal mapping to $5 \mathrm{p} 13$, and mutation detection in a SCOT-deficient patient. Am J Hum Genet. 1996;59(3):519-528. https://www.ncbi.nlm. nih.gov/pmc/articles/pmc1914926/

4. Fukao T, Mitchell GA, Song XQ, et al. Succinyl-CoA:3ketoacid CoA transferase (SCOT): cloning of the human SCOT gene, tertiary structural modeling of the human SCOT monomer, and characterization of three pathogenic mutations. Genomics. 2000;68(2):144-151. doi:10.1006/ geno.2000.6282

5. Sakazaki H, Hirayama K, Murakami S, et al. A new Japanese case of succinyl-CoA: 3-ketoacid CoA-transferase deficiency. J Inherit Metab Dis. 1995;18(3):323-325. doi:10.1007/bf00710423

6. Fukao T, Scriver CR, Kondo N; t2 Collaborative Working Group. The clinical phenotype and outcome of mitochondrial acetoacetyl-CoA thiolase deficiency (beta-ketothiolase or T2 deficiency) in 26 enzymatically proved and mutation-defined patients. Mol Genet Metab. 2001;72(2):109-114. doi:10.1006/mgme.2000.3113

7. Fukao T, Zhang GX, Sakura N, et al. The mitochondrial acetoacetyl-CoA thiolase (T2) deficiency in Japanese patients: urinary organic acid and blood acylcarnitine profiles under stable conditions have subtle abnormalities in T2-deficient patients with some residual T2 activity. J Inherit Metab Dis. 2003;26(5):423-431. doi: 10.1023/a:1025117226051

8. Fukao T, Shintaku H, Kusubae R, et al. Patients homozygous for the T435N mutation of succinyl-CoA:3-ketoacid CoA Transferase (SCOT) do not show permanent ketosis. Pediatr Res. 2004;56(6):858-863. doi:10.1203/01. pdr.0000145297.90577.67

9. Fukao T, Sass JO, Kursula P, et al. Clinical and molecular characterization of five patients with succinyl-CoA:3ketoacid CoA transferase (SCOT) deficiency. Biochim Biophys Acta. 2011;1812(5):619-624. doi:10.1016/j. bbadis.2011.01.015

10. Mitchell GA, Fukao T. Inborn Errors of Ketone Body Metabolism. In: Valle DL, Antonarakis S, Ballabio A, Beaudet AL, Mitchell GA. eds. The on line Metabolic and Molecular Bases of Inherited Disease. New-York: McGrawHill; 2001:chap 102. doi:10.1036/ommbid.130

11. Fukao T, Harding CO. Ketone Synthesis and Utilization Defects. In: Sarafoglou K, Hoffmann GF, Roth KS. eds. Pediatric Endocrinology and Inborn Errors of Metabolism. New-York: McGraw-Hill; 2017:chap 10. https://accesspediatrics.mhmedical.com/content. aspx ?bookid $=2042 \&$ sectionid $=154109797$

12. Fukao T, Mitchell G, Sass JO, Hori T, Orii K, Aoyama Y. Ketone body metabolism and its defects. J Inherit Metab Dis. 2014;37(4):541-551. doi:10.1007/s10545-014-9704-9

13. Abdelkreem E, Harijan RK, Yamaguchi S, Wierenga RK, Fukao T. Mutation update on ACAT1 variants associated with mitochondrial acetoacetyl-CoA thiolase (T2) deficiency. Hum Mutat. 2019;40(10):1641-1663. doi:10.1002/humu.23831

14. Fukao T, Nakamura K. Advances in inborn errors of metabolism. J Hum Genet. 2019; 64: 65. doi:10.1038/s100 38-018-0535-7 